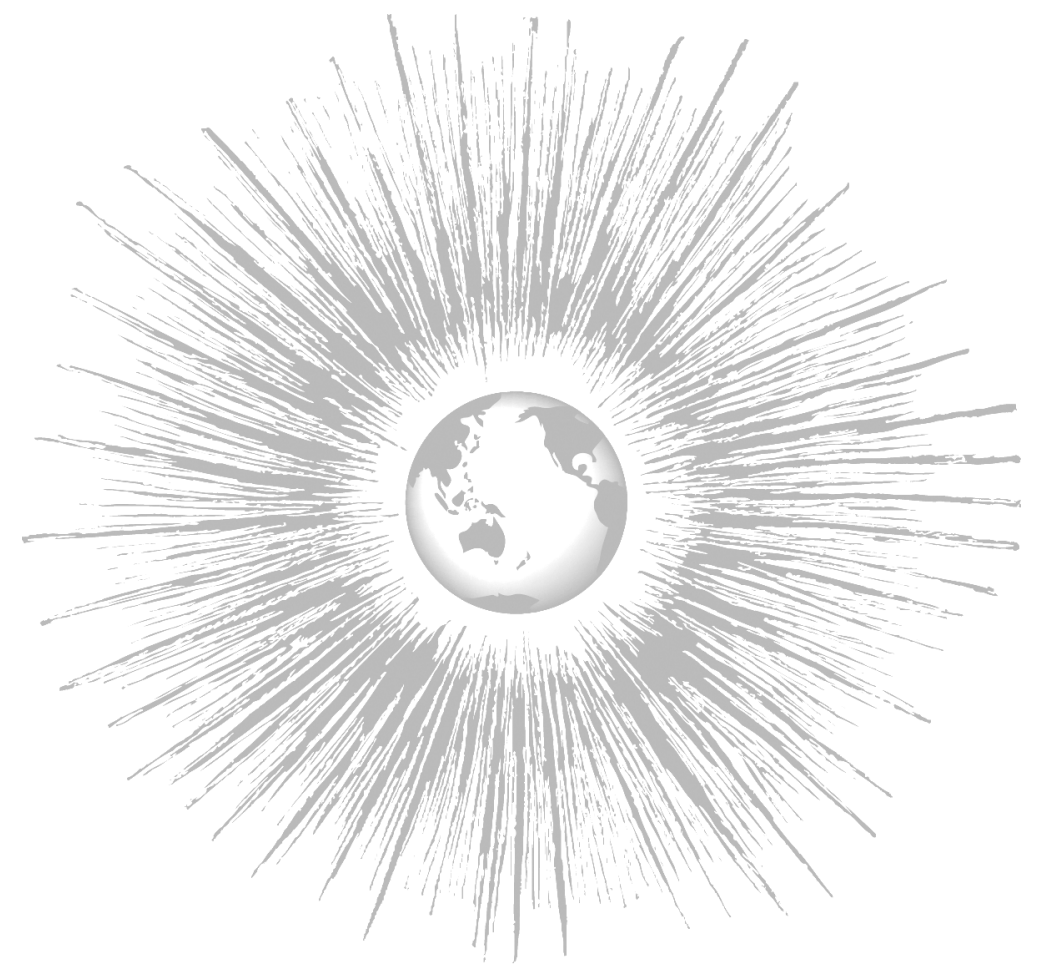

ABSTRACT:

The economic ascent of China in the past two decades is the most dramatic change in the capitalist world-economy of this period. Analyses focus on changes in government control of the economy, the availability of low cost workers for export production, the his torical characteristics of Chinese economy and society, and the role of the Chinese government as a developmental state. All high light key parts of China's economic ascent, but none addresses what we argue will be the critical component of future sustained economic ascent, if it is to take place in China: the role of raw materials and transport industries as generative sectors.

These generative sectors in the most successful historical cases articulate domestic economic development with the creation of new systems of international economic and political relations, ultimately restructuring the capitalist world-economy in support of a nation's ascent to core status and its ability to challenge the existing hegemon and other ascendant economies for hegemony. China is following the Japanese model of coastal greenfield heavy industrialization as state policies focus on deepening industrialization in steel, shipbuilding, and other heavy industries. However, following the models of earlier ascendant economies does not guarantee success. In this paper, we analyze the efforts underway in China to use steel, coal and other linked industries as driving forces for sustained economic ascent, and the potential consequences of these efforts for China and for the world economy.

\section{The Economic Ascent of China and the Potential for Restructuring the Capitalist WORLD-ECONOMY}

\author{
Paul S. Ciccantell \\ Stephen G. Bunker
}

\section{INTRODUCTION}

Q y any measure, the economic ascent of China in the past two decades is the most dramatic change in the capitalist world-economy of the late twentieth and early twenty-first centuries. Between 1985 and 2002, China's economy grew by an average of $9.65 \%$ per year and China's exports increased from Us $\$ 28$ billion in 1985 to US\$325 billion in 2002 . Analyses of this dramatic growth focus on changes in government control of the Chinese economy, the availability of tremendous numbers of low cost workers for export production by Japanese, European, U.S. and other transnational corporations, the historical characteristics of the Chinese economy and society, including China's historical role as the center of the world economy and the role of family business networks in organizing production and trade, and the role of the Chinese government as a developmental state.

All of these approaches highlight key parts of China's economic ascent, but none addresses what we argue will be the critical component of future sustained economic ascent, if it is to take place in China: the role of raw materials and transport industries as generative sectors. These generative sectors in the most successful historical cases of economic ascent articulate domestic economic
Paul S. Ciccantell

Department of Sociology

Western Michigan University

Sangren Hall

Kalamazoo, MI 49008

paul.ciccantell@wmich.edu

http://homepages.wmich.edu/ pciccant/
Stephen G. Bunker

Department of Sociology

University of Wisconsin-Madison

1180 Observatory Drive

Madison, WI 53706

bunker@ssc.wisc.edu

http://www.drs.wisc.edu/
JOURNAL OF WORLD-SYSTEMS RESEARCH, X, 3, FALL 2004, 565-589 bttp://jwsr.ucr.edu/

ISSN $1076-156 \mathrm{X}$

(C) 2004 Paul S. Ciccantell \& Stephen G. Bunker 
development with the creation of new systems of international economic and political relations, ultimately restructuring the capitalist world-economy in support of a nation's economic ascent to core status and its ability to challenge the existing hegemon and other ascendant economies for hegemony. From our theoretical and methodological perspective, we focus analytically on a critical set of industries and indicators and on the often highly conflictual process of developing a system of state-sector-firm relations that supports these generative sectors and, via a range of material, economic and sociopolitical mechanisms, the broader process of economic ascent.

The initial data for the generative sectors emerging in China are even more striking than the broader economic indicators discussed above. In the steel industry, Chinese steel production increased from 158,000 tons in 1949 to 40 million tons in 1980 and to 151 million tons in 200I, steel exports totaled 3.5 million tons in 200I (Brizendine and Oliver 200I; Serchuk 200I; Hogan 1999a, 1999b), and steel employment now totals approximately 3 million workers (Brizendine and Oliver 200I: 22). The Chinese government has begun closing small, globally uncompetitive steel mills and building new coastal steel mills using the latest technology and least costly globally available coal and iron ore, rather than relying on lower quality, higher cost domestic resources, as was formerly done under state policies of domestic economic self-sufficiency (Hogan 1999a). China is now the world's leading producer of steel, surpassing Japan, the U.S., and Europe (Serchuk 200I: 32). China also became one of the world's largest importers of iron ore ( 92 million tons in 200I), utilizing a global system of raw materials supply created by Japan during its economic ascent via a variety of innovations in technology and social organization of steel production, ocean shipping, and raw materials supply agreements.

China is following the Japanese model of coastal greenfield heavy industrialization to supply other industries at low cost (Todd I996; Hogan 1999a), as state policies focus on deepening industrialization in steel, shipbuilding, and other heavy industries. However, following the models of earlier ascendant economies, even in terms of fomenting what have historically been key generative sectors in the most successful cases of ascent, does not guarantee success, in part because older models may prove to be surpassed by new technological and organizational innovations by other competitors and in part because successful sustained ascent is a relational process of competition with the existing hegemon and other ascendant economies. Historically, for example, Germany surpassed both Great Britain and the U.S. in terms of steel production in the early twentieth century as part of its developmental drive, but German ascent eventually encountered both raw materials difficulties and direct conflict with the existing hegemon and other emerging rivals, with the conflict eventually resolved in favor of the U.S. China's efforts to follow Japan's model of ascent confront similar challenges from the existing hegemon, the U.S., and other competitors, including the European Union, Japan, and Russia. The economic and social consequences of closing and/or ending state support for inland industry, especially in the Northeast (a long-standing policy of autarky and domestic security under the Communist Party), are also a potential internal limitation of China's ascent.

In the following section, we discuss key contributions to understanding China's developmental model. In the third section, we outline our theoretical and methodological model, new historical materialism. In the fourth section, we present a brief summary of our research findings on the economic ascent of the four most dramatic cases of economic ascent in the history of the capitalist world-economy: Holland, Great Britain, the U.S., and Japan. In the fifth section, we analyze the role of generative sectors in China. The conclusion discusses the potential impacts of China's economic ascent on the future of the capitalist world-economy.

\section{LITERATURE REVIEW}

Analyses of China's dramatic growth focus on changes in government control of the Chinese economy (see, e.g., Morris et al. 2002; Lardy 1992), the availability of tremendous numbers of low cost workers for export production by Japanese, European, U.S. and other transnational corporations, and the historical characteristics of the Chinese economy and society, including China's historical role as the center of the world economy (Frank 1998) and the role of family business networks in organizing production and trade (Hui 1995; Irwan 1995; Wang 1991; Yeung and Olds 2000; Arrighi et al. 2002). All of these analyses identify key components of China's economic ascent as China's role in the world economy changed and expanded dramatically in recent decades.

An important recent advance in our understanding of the Chinese development model is the recognition that, despite very different state policies and roles in global geopolitics since World War II, the Chinese state since 1978 closely resembles the model of the East Asian developmental state (So 2003). The Chinese state from 1949 through 1978 created a legacy of a strong state developed in the context of the Cold War, fomented a strong nationalist sentiment and goal of creating a wealthy nation, created rural infrastructure and local institutions, and did all of this without creating a large foreign debt, all of which laid the foundation for the creation of a developmental state since 1978. The transition to a developmental state resulted from a combination of the ending of the Cold War, the collapse of the socialist development model, the search for lower cost production sites by China's neighbors as their costs of production increased, the 
increasing investment of Chinese diaspora capitalists in China, and the transition from revolutionary leadership to younger, more innovative leadership in China. Since 1978, the Chinese state has implemented reforms from above, taking advantage of the state autonomy and capacity created in the earlier era to carefully control and adjust the process of change in order to achieve high economic growth and to avoid many of the problems of the former socialist nations of Eastern Europe (So 2003).

All of these approaches highlight key parts of China's economic ascent in recent decades, identifying and explaining many of the components of this process. However, none addresses what we argue has been the central driving force underlying sustained economic ascent in earlier cases of economies that have risen to challenge the existing hegemonic power of their era: the role of raw materials and transport industries as generative sectors. If China is to create a sustained trajectory of growth for the future, these generative sectors, which are already key strategic sectors for the Chinese state, will have to play roles in China similar to those they played in earlier cases of dramatic and transformative economic ascent. These generative sectors in the most successful historical cases of economic ascent articulate domestic economic development with the creation of new systems of international economic and political relations, ultimately restructuring the capitalist world-economy in support of a nation's economic ascent to core status and its ability to challenge the existing hegemon and other ascendant economies for hegemony. From our theoretical and methodological perspective, we focus analytically on a critical set of industries and indicators and on the often highly conflictual process of developing a system of state-sector-firm relations that supports these generative sectors and, via a range of material, economic and sociopolitical mechanisms, the broader process of economic ascent.

\section{NEW HISTORICAL MATERIALISM AND ECONOMIC ASCENT}

In any rising economy, strategies for economic ascent must respond to and take advantage of contemporary technological, geopolitical, environmental, and market conditions in the rest of the world and of the nation's position and location within that particular global economy. They must also coordinate the physical characteristics and location in space and in topography of the various raw material resources actually or potentially available with the physical characteristics and location in space and topography of the national territory.

The beginnings of economic ascent require successful coordination of domestic technological advances, particularly in heavy industry and transport, with the external solution of access to cheap and steady sources of the raw materials used for heavy industry. The raw materials used in greatest volume pres- ent the greatest challenge and best opportunity for economies of scale. These economies of scale, however, drive a contradictory increase in transport cost, as the closest reserves of raw materials are depleted more rapidly as the scale of their industrial transformation increases.

The tension of this contradiction between the economies of scale and the cost of space foments technological innovation (a) in transport-vessels, loaders, ports, rails, etc., (b) in chemical and mechanical means of reducing component inputs per unit of output (e.g. coal and iron in steel), and (c) improvements in control of heat, pressure and the mix of chemicals that make the unit material inputs stronger and thus enable smaller, lighter amounts to perform the same work. All of these technological fixes drive each other, and all of them tend to generate increases of scale, thus exacerbating over the long term the very contradiction between scale and space that they are designed to solve.

The national economies that most successfully initiated technological and organizational solutions-internal and external-of this contradiction simultaneously (a) generated their own rise to economic dominance, (b) restructured the mechanisms and dynamics of systemic and hierarchic accumulation, and (c) expanded and intensified the commercial arena of raw materials trade and transport. Solutions to the raw materials problem of the tension between increasing economies of scale in raw materials extraction and transport and the accompanying diseconomies of the increasing cost of space require the coordination of multiple physical and social processes across geopolitical and physical space with domestic relations between firms, sectors, the state, labor, and new technologies. Rising economies resolve these problems at the same time as or even before they increase industrial competitiveness. These solutions stimulate complex processes of learning and of institutional change that fundamentally mold the organization of the national economy at the same time that they change international markets and the rules binding participants in them.

The challenges and the opportunities presented by the basic raw materials industries and by the transport systems on which they depend foster what we call generative sectors: sectors that, beyond creating the backward and forward linkages that underlie the concept of a leading sector, also stimulate a broad range of technical skills and learning along with formal institutions designed and funded to promote them, vast and diversified instrumental knowledge held by interdependent specialists about the rest of the world, financial institutions adapted to the requirements of large sunk costs in a variety of social and political contexts, specific formal and informal relations between firms, sectors, and states, and the form of legal distinctions between public and private and between different levels of public jurisdiction.

Generative sectors will be more numerous, more easily observed, and more 
efficacious in those national economies that are growing so rapidly that they must achieve massive increases in throughput and transformation of raw materials. The concept is relational, however, within a world-systems perspective, and thus implies that generative sectors in a rising economy will have significant consequences for economies that export raw materials or trade in other kinds of goods. We have been developing a series of comparative historical cases that analyze how generative sectors form around raw materials and transport (Bunker and Ciccantell 1995, 2003a, 2003b). Now we are taking the lessons from that comparative historical analysis to diagnose a case of still uncertain outcomes.

The semantic form of the notion "generative sector" connotes that other sectors, or changes in those sectors, are generated. Chandler (1965, 1977) demonstrated that the railroads in the U.S. adapted to the problems and opportunities of moving multiple cargos over great distances at high speeds by devising organizational forms that could coordinate, dispatch, and monitor entire trains, and eventually individual cars, from and to multiple locations. He claimed that the telegraph companies, faced with the need to coordinate and regulate the flows of multiple messages from and to multiple locations, adopted the "template" that the railroads had developed.

Chandler does not consider how the telegraph, thus formed, increased the efficiency, safety, complexity, and profits of railroads. Our model of generative sectors, therefore, includes consideration of feedback, or auto-catalytic loops (Prigogine and Stengers 1984), between generative sectors and the sectors that they foment or stimulate to change. If raw materials access strategies require new scales of transport, and thus new technologies, new design, and new infrastructure, we expect that, for example, successful access to cheaper iron ore and coal will both require and generate technical solutions to transport costs, such that the design and construction of larger ships, better railways, larger ports, more capacious warehouses, and other infrastructure will create demand for more steel, and potentially for higher quality steel, in volumes, or at levels of throughput, that both make possible technological innovation and allow full use of capacity required to reduce unit costs of steel. Reduced unit costs of steel make shipbuilding cheaper and more competitive and further reduce unit costs of iron and coal transport. These feedback loops cheapened, deepened, and accelerated the synergies between iron ore, coal, computerized continuous casting and hot rolling, vastly larger harbors, the construction and deployment of large dry bulk carriers, and the relocation of heavy industries and their downstream consumer industries around deep-water ports.

In this sense, steel is a generative sector, but transport is not simply a generated sector. It is rather in a feedback or auto-catalytic loop that intensifies the growth and innovation in the generative sector, the steel industry. The progression toward increasingly tight coupling at greater technical economies of scale across greater spaces and multiple sovereignties with greater levels of production that characterizes the unfolding of the world-system means that only economies where effective generative sectors emerge can rise to economic competitiveness or even dominance.

Generative sectors are not necessarily the sectors in which profits are highest, even though high profit sectors (whether gold and silver in the seventeenth century or computer technology in the twentieth century) are those that typically attract the most analytical attention (see, e.g., Arrighi 1994; O'Hearn 2002). However, as we have shown elsewhere (Bunker and Ciccantell 2003a, $2003 \mathrm{~b}$ ), highest profit sectors are not necessarily generative sectors, and generative sectors are not necessarily the highest profit sectors. Instead, generative sectors provide the material building blocks, cost reductions across many sectors to increase competitiveness, and patterns of state-sector-firm relations and other institutions that combine to drive economic ascent.

But why should raw materials continue to be a concern in the current era of high technology industries and supposed dematerialization (see, e.g., Herman et al. 1989, and Larson et al. 1986)? Claims about dematerialization became possible as heavy industry in the U.S. and Western Europe became increasingly uncompetitive since the ragos and closed. However, these industries were simply relocating to lower cost producing nations in the semiperiphery and periphery such as South Korea, Brazil, and China. The world economy uses more material every year; it is simply produced increasingly outside the core nations. Moreover, the assumptions of dematerialization in the core are called into question by observations of the subject of much of the flows of communication (e.g. shipments of material products) and the industries in which productive capital from the core nations is invested around the world (e.g. steel production in China today). Even if material processes of production are now the object of a smaller portion communication or capital, the technically driven flood of communication and capital is so much greater than it once was as to suggest that information and investment, no matter how global, are still about material things in specific places.

Steel today, for example, is seen as an anachronistic relic in the U.S. because of the industry's collapse since the early I970s in the face of first Japanese and then later other global competition. However, under conditions of rapid economic growth in China in recent years, huge and rapidly growing quantities of steel are needed to build office buildings, factories, roads, and other infrastructure, in addition to the products being exported, and simultaneously generates huge profits for steel producing firms, many of them operating in partnership 
with Japanese, South Korean, and European steel firms. Steel may be "past its prime" in the product life cycle of U.S. industry, but it remains a key ingredient in the process of rapid economic ascent in China.

\section{THE ROLE OF GENERATIVE SECTORS IN HOLLAND, GREAT BRITAIN, THE U.S. AND JAPAN}

Four key cases of economic ascent, Holland, Great Britain, the U.S., and Japan, provide instructive examples of the role of generative sectors in creating and restructuring inequality between national economies, driving ascent to trade dominance within the world economies, and driving the material intensification and spatial expansion of production and trade in the world economy. The critical competitive advantage underlying Dutch ascent was its geographically based control over river routes to the agricultural lands and forests of Poland and Germany. Gaining control over the transport routes to these upriver regions and therefore over their raw materials exports was the key raw materials challenge for Dutch shipping and shipbuilding firms and the Dutch state. Overcoming this challenge provided the raw materials needed for Dutch shipping and shipbuilding (Boxer 1965; Barbour 1950; Wallerstein 1974, 1982), key generative sectors that transformed the global economy (Bunker and Ciccantell 2003a).

The Dutch shipbuilding and shipping industries spread technological innovations in labor saving machinery, organizational techniques, the adaptation of windmill technologies to wood sawing, economies of scale in protoindustrial shipyards, and the development of linked industries of finance, warehousing, and other industries such as textiles that could benefit from these types of innovations. The Dutch state intervened in shipbuilding with significant subsidies because no firms had the resources to develop the technologies to make Dutch shipping the most competitive in the world, the key to supporting Dutch regional and world trade competitiveness (see Boxer 1965; Barbour 1930, 1950; Wallerstein 1974, 1982). This established the pattern for Dutch hegemonic ascent. At the same time, these generative sectors restructured agricultural production systems and the use of timber in the Rhine and Baltic regions, reshaping these areas into extractive peripheries that exported raw materials to Holland (Bunker and Ciccantell 2003a).

The next ascendant economy and eventual hegemon, Great Britain, specialized in the development of the warships used to displace Holland as the economic and political center of the capitalist world economy. Timber acquisition soon became difficult in Great Britain because of increasing competition for diminishing supplies of large oak trees, but Great Britain's North American colonies provided timber via state-claimed large trees for shipbuilding (Innis
1956). This supply pattern of raw materials from North America was replicated in many industries during the I700s and I800s (Bunker and Ciccantell 2003b).

James Watt's vastly improved steam engine began a shift away from wooden shipbuilding and toward the development of internal canal and railroad transport and iron industries as generative sectors. Watt's steam engine made vast reserves of deeply buried coal suddenly available on a large scale at low cost to power Britain's Industrial Revolution (Mathias 1969: 134-I35; Rosenberg and Birdzell 1986: 150-15I). Within a few decades, the steam engine was adapted for railroad transport, simultaneously freeing Britain from increasingly expensive, complex efforts to build canals and creating a growing synergy between railroad transport and the iron and later steel industries during the nineteenth century. British ironmasters developed a series of innovations in iron and steel production that made British iron and steel the most efficient and highest quality in the world and created many new uses in infrastructure, transport and industry for steel (Isard 1948; Hobsbawm 1968; Harris 1988; Albion 1926; Bunker and Ciccantell 2003b).

In the mid-nineteenth century, the steam engine was also applied to water transport, rejuvenating Britain's shipbuilding and shipping industries on the basis of steamships that linked the distant parts of the British empire; shipbuilding consumed massive amounts of raw materials that were often transported on steamships themselves (Mathias 1969; Rosenberg and Birdzell 1986). The combined impacts of railroads, steamships, and the raw materials industries on which they depended revolutionized industry and finance in Britain (Hobsbawm 1968). Moreover, these developments further tied Britain's internal raw materials peripheries to the process of capital accumulation. At the same time, the innovations and size of the steamship fleet for international trade and warfare gave Great Britain a huge lead in the colonial scramble of the late I8oos, enabling Great Britain to incorporate ever more distant raw materials peripheries into the British cycle of capital accumulation. The coal, iron, steel and linked transport industries became generative sectors driving British economic ascent and hegemony. This is the essence of the role of generative sectors in economic ascent: what might be termed "virtuous cycles" of linkages between raw materials and transport industries drove capital accumulation in Britain during its phases of economic ascent based on incorporating first internal and later external peripheries during its period of hegemony (Bunker and Ciccantell 2003b).

Britain's growing reliance on the agricultural and industrial development of the American colonies and then the U.S., particularly the development of the New England shipbuilding and shipping industries, laid the foundation for the economic ascent of the U.S. Abundant U.S. timber supplies, numerous river networks to transport timber to the coast, the transport cost advantages of pro- 
cessing timber into ships at the rivers' mouths rather than shipping to English shipyards, and the U.S.' status as a British colony gave U.S. shipbuilding and shipping industries a tremendous competitive advantage in the world economy. These industries were generative sectors in the eighteenth and first half of the nineteenth centuries, transporting bulk and luxury goods over long distances to Europe, China and other parts of the world (Morison 1921; Heinrich 1997; Albion et al. 1972; MacDougall 1993; Bunker and Ciccantell 2003b).

During the mid-I80os, the center of gravity of the U.S. economy shifted westward to the center of the continent. The proximity of dense forests of high quality timber hugely enhanced commerce on the Great Lakes. The spread of grain agriculture and the demand for coal drove a vibrant shipbuilding industry around the lakes. Highly decentralized charcoal-fueled iron plants supported early U.S. industrialization, but by the mid-nineteenth century both iron ore and trees became scarcer around the established plants. The discovery of copper and iron in huge high-grade deposits in the upper peninsula of Michigan in the I840s supplied the first expansion of iron production. The coincidence of increased demand with the opening of new transport routes and the discovery of new and richer deposits fed back into the further investment in mining, locks, canals, and larger vessels that required further investments to expand the locks (Bunker and Ciccantell 2003b).

The completion of the Sault Ste. Marie locks in 1855 opened up the vastly larger Mesabi Range iron deposits in Minnesota. Boat sizes increased, the technology of boat motors developed greater machine power very rapidly, hulls were increasingly made of metal (something necessary for size to increase), mining and loading were increasingly mechanized, and integration with rail systems proceeded (both physically as infrastructure but also as corporate strategy as huge combines and corporations emerged around the nexus of mining, transport, processing, and sale) (Holbrook 1939; Warren 1973; Hogan 1972; Bridge [1903]1991; Livesay 1975; Reutter 1988; Serrin 1992). In other words, Great Lakes mining and transport fed each other in very much the same way that logs and boats did in Holland, but at a vastly larger scale of material and space and capital with larger corporate units and a more active state (Bunker and Ciccantell 2003b).

The U.S. state supported U.S. Steel and the concentration of railroads via selective enforcement of antitrust laws that allowed concentration and via subsidies to the railroads, with much of this funding used to purchase steel rails from U.S. Steel. U.S. antitrust actions against the railroads, U.S. Steel, and Standard Oil marked the divergence of state interests in supporting other sectors and these previously tacitly accepted monopolies' efforts to maintain their control (Holbrook 1939; Warren 1973; Hogan 1972; Bridge [1903]1991; Livesay
1975; Reutter 1988; Serrin 1992; Bunker and Ciccantell 2003b). The industries, transport infrastructure, and overall pattern of state-firm relations established by these generative sectors remained in place and slowly obsolesced (Ciccantell 200I), but their impacts continue to shape the U.S. political economy, as the current conflict over the future of the steel industry demonstrates.

After Japan's industrialization drive of the early Igoos depleted Japan's limited coal, iron ore, and copper reserves, the Japanese state and Japanese firms sought to gain access to raw materials via direct imperial conquest of neighboring resource-rich areas of China, East Asia, and Southeast Asia (So and Chiu 1995; Borden 1984). However, this raw materials access strategy brought Japan into direct military conflict with the United States, Great Britain, the Soviet Union, and China and resulted in defeat in World War II, the dismemberment of the empire, and severe economic and political crises (Bunker and Ciccantell 1995, 2003b).

The U.S. government, seeking to promote Japanese development for geopolitical reasons as a bulwark against communism in Asia, worked with the Japanese steel mills and the Japanese state to devise a model to guarantee long term secure access to metallurgical coal and iron ore from Australia. The new model relied on long term contracts, at first forced upon them by Australia and the U.S., rather than using the wholly-owned foreign direct investment model utilized by U.S. and European steel firms to gain access to foreign raw materials sources. This new model accommodated the resource nationalism of host nations such as Australia, while in the process restructuring worldwide flows of metallurgical coal from mainly domestic movement to transoceanic trade flows (Bunker and Ciccantell 1995, 2003b).

Japanese shipyards, supported by huge state subsidies and long term shipping charters from the Japanese steel mills, began with imported U.S. shipbuilding technology attracted by government subsidies and then began conducting independent research and development on the construction of larger petroleum tankers and bulk carriers and the construction of large shipyards capable of building such large ships (Chida and Davies 1990). Japanese shipping firms associated with the major industrial groups owned and operated these ships. These Japanese industrial groups control ocean shipping of raw materials on an FOB raw materials exporting port basis (shipping costs paid by the buyer from the exporting port to Japan) so that Japanese importers captured any reductions in transport costs caused by technological improvements or changes in world shipping market conditions (Bunker and Ciccantell 1995, 2003b).

Additionally, the Japanese government provided subsidies for the construction of Maritime Industrial Development Areas (MIDAs) in Japanese ports that eliminated the need for internal transshipment in Japan of raw materi- 
als imports. Japan's coastline was ideally suited for this form of linkage and transport-based development (Kosai and Ogina 1984: 60-6I). This transport pattern allowed Japanese steel mills and shipping firms to take advantage of the tremendous economies of scale available in bulk shipping to dramatically reduce production costs of steel in Japan by capturing all of these benefits for themselves (Bunker and Ciccantell 1995, 2003b).

These economies of scale in raw materials extraction and transport are tightly linked to economies of scale in steel production itself. Abegglen and Stalk (1985) argue that these three types of economies of scale, including the construction of new integrated steel mills in Japan from the I950s to the I970s that were, when built, the largest or almost the largest in the world, gave Japan a tremendous competitive advantage in the world steel industry. Because Japan lacked domestic supplies of metallurgical coal and iron ore, Japanese steel firms could search out and help develop the lowest cost suppliers in the world with access to large scale ocean shipping potential, resulting in significant raw materials cost advantages for Japanese steel firms (Abegglen and Stalk 1985: 73-78). As American and Japanese development planners foresaw in the late 1940s, the steel industry became the linchpin of a number of linked industries which complemented one another in a "virtuous cycle" of economic development based on generative sectors in shipbuilding and steel, transforming Japan into the world's second largest economy and the United States' most formidable economic competitor. This pattern of metallurgical coal supply relationships was replicated in a number of other raw materials peripheries around the world (Bunker and Ciccantell 1995, 2003b).

The Japanese steel mills initially learned to blend metallurgical coals to reduce dependence on very expensive imports of U.S. coal, but subsequently converted this skill into a broader system of controlling cost and quality by closely specifying the characteristics of coal to be purchased in each long term contract with its diverse supplying mines, then mixing these varieties from stockpiles in Japanese MIDAs. The Japanese steel mills and the Japanese state organized coal and iron ore buying cartels that drove down the costs of acquiring raw materials via coordinated action (Koerner 1993; Anderson 1987; Swan et al. 1999; Graham et al. 1999; Bunker and Ciccantell 2003b).

The Japanese steel mills and the Japanese state created the "ABC Policy" (McMillan 1985) to diversify sources of supply, principally among Australia, Brazil and Canada, to protect against supply disruptions and raw materials suppliers' efforts to negotiate higher prices for their raw materials exports. Japan's raw materials diversification policy incorporated Australia, Brazil, Canada, South Africa, Indonesia, and other nations to protect against resource nationalism in its raw materials suppliers. The Japanese state supported the develop- ment of MITI (Ministry of International Trade and Industry) as a mechanism for coordinating the steel, shipbuilding and shipping firms and for gathering information about and negotiating with raw materials supplying firms and states. Trading companies helped to coordinate the coal and iron ore buying cartels and prevented international competition among Japanese steel firms (Bunker and Ciccantell 2003b).

The U.S. and Japan in the post-World War II era competed in the steel industry as scale increased and chemical composition and quality requirements became more precise. Japan's rapid industrialization and ascent to preeminence in the global economy resulted in global shifts in raw material extraction, processing, and trade. Under 20 percent of all iron ore mined in 1960 entered transmaritime trade; two decades later, over 35 percent was shipped overseas for processing. Ton-miles of iron transported increased over 600 percent during the same period. Coal was also transformed from a locally and regionally traded commodity to a globally traded commodity; ton-miles transported increased II $75 \%$ percent between 1960 and 1980 . The cargo capacities of the largest oil and bulk carriers increased over 30 fold between 1958 and 1984 , led by innovations in Japanese shipyards (Chida and Davies 19990), with corresponding increases in port sizes and capacities for the export of iron, coal, and oil around the world (Tex Report 1994a, 1994b). World patterns of ownership, market share, and location were radically altered in all of these industries. Just as in earlier cases of dramatic ascent, Japan's ascent fundamentally and materially restructured the world economy in support of Japan's domestic development. Although Japan did not become hegemonic, its ascent transformed the capitalist world-economy in ways similar to these earlier cases of economies that did become hegemonic. In Japan, the difficulties encountered by sunset industry efforts during the I970s and 1980 s and the very slow, still only partly completed efforts to restructure the banking industry over the past decade (Katz 1998) demonstrate the difficulties of changing these patterns and the conflicts that can ensue between firms and the state.

One critical component of economic ascent in each of these four cases was the relationship between the existing hegemon and the ascendant economy. In the case of Holland, Dutch shipbuilding and shipping began their role as generative sectors by doing the heavy bulk hauling for the Portuguese empire when Holland was under Portuguese rule. For Great Britain, recruitment of Dutch shipbuilding craftsmen to help develop the British shipbuilding industry and long term dependence on war and piracy to acquire Dutch ships played key roles in British imperial strategies. For the U.S., the use and adaptation of British technologies and capital in steel and railroads in the wider national spaces and richer resource base of the U.S. provided the critical building blocks for 
these generative sectors. After World War II, Japanese use of capital and technology in shipbuilding and steel from the U.S. and U.S. diplomatic help to gain raw materials access were essential to the creation of the Japanese development model. In recent years, the growing relationship between Japan and China in steel, including supplying Japanese technology and capital for developing the Chinese steel industry and following the Japanese model of coastal steel mills and raw materials access, has replicated in important ways this longstanding historical pattern. As we will discuss in the following section and in the conclusion, China's ascent may make it a competitor for hegemony, or Japan and China may establish a mutually supportive relationship similar to that between Great Britain and the U.S. during the I70os and I80os (Bunker and Ciccantell 2003b).

In summary, in each of these cases of economic ascent, raw materials and transport industries were generative sectors that drove these nations' development and their restructurings of the world economy. The pattern of tightened coupling of state-sector-firm relations, necessitated by the increasing complexity of raw materials access created by each of these ascendant economies, contributed to the cumulatively sequential evolution of the world economy, raising the bar for each subsequent potential ascendant.

\section{THE ROLE OF GENERATIVE SECTORS IN CHINA}

The steel, transport, and other linked industries in the generative sectors of China began to develop during the first half of the twentieth century under the aegis of invading imperial powers, most importantly the Japanese, who built China's first steel mill at Anshan (Serchuk 20oI; Hogan 1999a). Under the Communist Party from 1949 through the late I970s, government policy focused on domestic self-sufficiency in key economic sectors, including steel (Dorian 1999). During the I950s, the Soviet Union provided technical support and technology, including building steel mills in China, such as the Wuhan mill (Hogan 1999a). The Chinese government supported the development of a large steel industry, with production of 40 million tons in 1980 (Serchuck 200I). These steel mills were relatively small scale and often located far inland for security purposes. Rural areas of China supplied coal and iron ore, and the coal industry became one of the most important employers in rural China, producing 871 million tons of coal in 1985 and employing millions of people. The mines and steel mills were linked by a limited and antiquated railroad transport system that severely limited inter-regional trade and raised costs of production; this transport system also made imports and exports of resources extremely difficult.

Chinese government policies for steel, coal and linked industries began to change in 1978, with minerals and metals industries planned to be key com- ponents of efforts to expand China's role in the global economy (Dorian 1999; Schneider et al. 2000). The pace of change accelerated in the I980s as part of the broader process of economic reform instituted by the Communist Party (Dorian 1999). For the steel industry, this meant a dramatic increase in steel capacity and production, often from new steel mills located in coastal regions (Ruiyu 1999). Steel production almost quadrupled in China between 1980 and 200I, rising from 40 to $15 \mathrm{I}$ million tons, and extensive efforts were made to improve steel technology both through imports and domestic research and development, including raising the continuous casting rate dramatically and slowly replacing antiquated technologies (Ruiyu 1999; Liu and Jin 1994; Hogan 1999a, 1999b).

To supply these mills, imports of far higher quality Australian, Brazilian and other imported iron ore increased from only io million tons in 1985 and I4 million tons in 1990 to $4 \mathrm{I}$ million tons by 1995 and 92 million tons in 200I, ranking behind only Japan and the European Union in size (International Bulk Journal 2002: 28). Several ports serving coastal steel mills, including Dalian, Tangshan, Tianjin, and Majishan increased or are increasing their capacity to accommodate 100,000 to 200,000 deadweight ton ships bringing ore from Australia and Brazil (International Bulk Journal 2002: 27-28; Hogan 1999a, 1999b). Plans are being made for even larger scale ports, since a contract was recently signed with the world's largest iron ore exporting firm, CVRD (Companhia Vale de Rio Doce) of Brazil, for the construction of a 450,000 dwt bulk ship. This will be the world's largest bulk carrier and is planned to take Chinese coal to Brazil and Brazilian iron ore to China.

For the coal industry, this emphasis on steel and electric power as generative sectors to supply the broader economy entailed increases in domestic capacity and production, as well as an emphasis on exports of coal. China now rivals Australia as the world's largest coal exporter, with China exporting 55 million tons of coal worth US\$1.5 billion in 2000 (International Bulk Journal 2002: 54; Schneider et al. 2000; Tse 2000).

By 1995, China became the world's largest steel producer. This dramatic increase in capacity and production, however, encountered three major problems. First, in terms of supplying the growing demand for steel from China's manufacturing industries, important limitations on the quality and product lines of the Chinese steel mills required significant volumes of imports of products such as steel sheet for appliance and automotive production (Serchuk 200I: 32; Hogan 1999a, 1999b). Second, aging and often antiquated technologies at many steel mills contributed to these quality problems and to management difficulties and environmental problems (Brizendine and Oliver 20or; Serchuk 200I; Hogan I999a, 1999b). Third, extremely low levels of productivity per worker made Chinese steel uncompetitive globally without extremely low cost 
labor. Chinese steel mills produce 37 tons of steel per year per employee, while in Japan, Europe and the U.S. output per employees is closer to 400 tons (Brizendine and Oliver 200I* 22).

The Chinese government instituted a series of new policies over the last seven years in order to address these problems in the steel and coal industries in particular and more generally to prepare the broader economy for joining the World Trade Organization and to increase global competitiveness. In both steel and coal, government policies call for restructuring steel mills and firms to improve productivity and reduce employment, including closing many small steel mills and coal mines and encouraging concentration into a smaller number of more competitive and potentially more profitable firms (Brizendine and Oliver 200I; Mehta 1998; Hogan 1999a, 1999b). Investment in steel has been refocused from building new capacity, with three new coastal steel mills of ten million tons per year capacity each postponed indefinitely (Serchuk 200I), to improving steel quality and broadening Chinese production into high end product lines to replace imported steel (Brizendine and Oliver 200I; Serchuk 200I; Hogan 1999a, 1999b).

A key strategy for this technological upgrading has been to attract foreign firms as joint venture partners and technology suppliers, a strategy that has proven very effective. Most of the world's leading steel mills and firms supplying technology to steel mills are now involved in dozens of projects in China, as are Japanese trading firms and banks, including Nisshin Steel, Nippon Steel, Sumitomo Metal Industries, Mitsui and Co., Mitsubishi Corporation, Mitsubishi Heavy Industries, the Industrial Bank of Japan, Sakura Bank, Dai-Ichi Kangyo Bank, Sanwa Bank, Marubeni Co., and Itochu International Corp. of Japan, the Asian Development Bank, Posco of South Korea, and Thyssen-Krupp of Germany (Dorian 1999; Brizendine and Oliver 200I; Huskonen 200I; Hogan I999a and 1999b).

Efforts to increase the global competitiveness of China's steel industry and other raw materials processing industries also include another form of cooperation with foreign firms: Chinese joint ventures in iron ore, copper, and other types of mines and steel mills in Australia, Papua New Guinea, Chile, Peru, the Philippines, and New Zealand (Dorian 1999; Tse 2000). These overseas investments by Chinese firms as minority joint venture partners and buyers of output under long term contracts are explicitly modeled on the raw materials access strategies of Japanese steel firms, reducing the costs and risks to the importing firms while transferring the vast majority of the costs and risks of large investments in mines and infrastructure to firms and states in the exporting region (Bunker and Ciccantell 1995, 2003a, 2003b).

For the coal industry, a major effort to increase exports during the I980s and early 1990 s has taken a subordinate position to providing coal to steel mills and especially for electricity generation to the rapidly growing cities of the southeast coast (Todd 1996: 52). Several coal ports were previously targeted for upgrading for export sales and as locations for the new coastal steelworks, including the new industrial development area at the natural deepwater harbor at Rizhao (Todd 1996). However, many of these ports now focus on transshipping coal railed from internal coal mines, loading the coal onto small bulk carriers for carriage to the southeast coast cities. Rail network upgrading is underway as well to improve interregional flows of coal and other cargoes, but coastal shipping remains the key link for getting coal to the industrializing southeast (Todd 1996; Schneider et al, 2000). Efforts to promote foreign investment in coal production continue, including in the relatively undeveloped but geologically rich coal regions of Inner Mongolia, such as a joint venture to upgrade China's major coal mines with an Australian firm that included a US $\$ 200$ million investment and the construction of an underground coal pipeline, coal washery and port facilities between a Chinese government firm and U.S. and Australian partners for an investment of Us $\$ 888.6$ million (Dorian 1999; Tse 2000). Restructuring of the coal industry closed more than 40,000 small, uncompetitive coal mines, reducing capacity by 320 million tons per year and contributing to a decline in coal production from $\mathrm{I} .38$ billion tons in 1996 to 880 million tons in 2000 (International Bulk Journal 1999: 23; Tse 2000).

The most fundamental obstacle to these strategies for increasing the competitiveness of the Chinese steel and coal industries derives from the social costs of closing high cost mills and mines and ending the jobs of millions of workers. In many of China's industrial regions developed between 1949 and the early I980s, particularly in the northeast, unemployment rates already reach levels estimated at 30\% to $70 \%$ in many cities (Brizendine and Oliver 200I: 22). High unemployment levels are creating tremendous social unrest and putting a great deal of budgetary strain on local and regional governments. These governmental units have pressured the central government to slow the restructuring in steel and coal in order to protect jobs and tax revenues in these already declining regions, with at least some success. The emerging class conflict between the unemployed and state officials, many of whom are using their government positions to transform themselves into capitalists, in combination with growing financial crises because of nonperforming loans, financial losses by stateowned firms, and the growing government budget deficit, create tremendous challenges for the Chinese state and for the sustainability of the Chinese development model (So 2003).

These social costs and problems underscore the challenges involved in a problem of scale that may be unique to China among the world's rapidly ascen- 
dant economies: the challenge of the scale of the population to be employed, provided with goods and services, and persuaded to support the legitimacy of the state and its model of economic development, political relations, and their socioeconomic and environmental consequences. For Holland, Great Britain, and the U.S., issues related to population focused much more on potential shortages of labor and the need to create political, economic and organizational strategies to guarantee adequate supplies of labor at reasonable costs. In the U.S. and Holland in particular, labor shortage and technological innovation created a win-win situation for labor and capital because it made labor more productive and capital more profitable. However, this is not the case in China today. Only in Japan after World War II was the issue of how to employ millions of unemployed soldiers and workers displaced from wartime factories and agricultural production a salient concern for an economy that later constructed a sustained pattern of economic ascent. This challenge facing China, common to many nations of the periphery and semiperiphery during the twentieth century, but on a much greater scale in China, presents a fundamental challenge to sustained ascent, since the shift from the earlier model of autarky to greater openness and global competitiveness is creating immense numbers of job losses and growing political unrest.

This scale of population, however, also presents an important opportunity, as the multitude of foreign firms investing in China well know: a market of almost one quarter of the world's population under one political unit with a common language and culture that simplifies marketing efforts and offers the potential for huge revenues and profits. While even the most successful of these efforts have only met with limited success and many others have yet to prove profitable, the potential offered by the scale of China's population remains an important economic factor and lever for the Chinese government to use with potential foreign investors.

Another key strategy for the Chinese government in the early twenty-first century is massive deficit spending on infrastructure as a form of "New Deal" to resolve infrastructural problems and simultaneously employ huge numbers of workers and stimulate continued rapid economic growth. Government investment plans include spending US $\$ 200$ billion turning the city of Chongqing in southwestern China into a transportation and industrial hub near what had been (until these and other government development plans were announced) the world's single largest infrastructural investment, the us $\$ 30$ billion Three Gorges Dam (Kahn 2003). The Chinese government is investing us $\$ 60$ billion in new road construction during the end of the 1990s and early 2000s, US\$30 billion on railroad construction during the same period (33 Metalproducing 1998: 42), and billions more on port construction (International Bulk Journal
2002). These infrastructural investments derive from efforts by the central government to ensure support from city and regional governments by attempting to reduce unemployment and further economic development, but this program and the resulting deficit spending are creating potential government fiscal and financial sector problems (Kahn 2003).

Closely linked to these infrastructural investments are efforts to attract foreign investment into the interior regions of China in order to reduce interregional disparities. WTO accession and a series of new government regulations regarding foreign investment (Tse 2000) opened the door to additional foreign investment, and the government launched a "Go West" campaign (Tse 2000) to lure foreign companies to invest in the interior via a new series of tax and other incentives (Tse 2000; Todd 1996). This strategy includes efforts to link ports with coal producing areas to spread growth from the coast inland via coal mining-based development (Todd I996).

Based on our earlier research on the process of hegemonic succession and the work of Arrighi (1994), one of the most interesting questions about the long term sustainability of China's economic ascent is the role played by the most recent case of sustained economic ascent, Japan, in China's ascent. In each earlier case of rapid ascent, the existing hegemon played a key role as the supplier of capital and technology to the rising economy as part of what Arrighi (1994) analyzed as the period of financialization and decline in the existing hegemon and the efforts of financial capital in the hegemon to find new opportunities for investment in rapidly growing economies.

At least to some extent, Japanese firms play this role in the ascent of China, both in the manufacturing growth in southeastern China over the last fifteen years, the focus of most analyses of Chinese economic growth, as well as in the steel, transport and other raw materials industries on which we focus. The largest and most modern steel mill in China, Baoshan, opened in 1985 on the southeastern coast near Shanghai and was built with technical assistance from Nippon Steel and other Japanese companies (Hogan 1999a), an explicit replication of the Japanese steel-based MIDA program. Japanese steel firms are currently joint venture partners in several steel mills and steel processing plants (Tse 2000), supplying capital and technology to their Chinese partners. In other raw materials industries, a wide variety of Japanese raw materials processing firms, trading companies and banks are playing similar roles (Tse 2000). Japanese firms supplied 5-16\% of total annual inflows of foreign direct investment in China from 1986-2002, with 7-9\% the usual range (Invest in China www.fd.gov.cn), making Japan the fourth largest foreign investor. However, because the single largest single investor according to available data has been Hong Kong throughout the period and much of this investment is in fact from 
other nations, including Japan, it is difficult to state with certainty the exact total share of Japanese investment in China. Another important example of this direct transfer of the Japanese model, Japanese technology, and Japanese investment is the new industrial development built on the natural deepwater port of Rizhao. The development plan includes a large capacity rail connection to the interior coal fields that is partially completed, a port completed in 1986 that can load and unload capesize ships, with the goal of importing iron ore and exporting coal to Japan, an integrated steel mill and industrial complex that has been at least postponed, and all the other components of a growth pole. This particular coastal growth pole, however, confronted serious problems by the mid-I99os and many of the planned facilities have not been built and the city remains only a minor part of China's coal transport network and industrial base (Todd 1996).

These efforts to explicitly follow the Japanese post-World War II model of development, and especially the cases of Baoshan and Rizhao, illustrate both the potential benefits and risks of following this model and creating an integrated set of generative sectors in steel and transport. Steel and other heavy industry based growth poles following this model can be found on the coasts of a number of nations in Europe, Asia, Latin America and Africa. However, most, despite billions of dollars of investment by states, international financial institutions, and domestic and foreign firms, remain at best poorly integrated enclaves that have failed to generate sustained economic growth. State policies and the availability of funding are only parts of the broader process of international competition that shapes the developmental trajectories of particular growth poles, regions and states within the world economy. The strategies, successes and failures of other ascendant economies and the existing hegemon shape the technological, organizational, socioeconomic and political parameters that determine global competitiveness, and more successful rivals can effectively circumscribe the best policy choices and largest investments of other competitors. In the steel industry since World War II, for example, dozens of nations invested billions of dollars in what has been in some cases this driving force of economic development. However, the steel mills built by Japanese firms with the support of the Japanese state and those built following the Japanese model in South Korea have been far more successful in terms of international competitiveness than similar complexes in Europe, Latin America, and other nations in Asia. The outcomes of these developmental efforts are highly contingent on the strategies of other competing economies, and the long term sustainability of China's efforts to sustain its economic ascent by following the Japanese model is far from assured.

\section{CHINA AND THE FUTURE OF THE CAPITALIST WORLD-ECONOMY}

The Chinese government and Chinese and foreign firms are clearly moving to deepen industrialization by investing in and promoting what have historically been the key generative sectors of steel, transport and other linked industries, recognizing both the fundamental challenges of resolving the material input needs of a rapidly growing economy and the opportunities these challenges create for generative sectors to drive economic ascent. The example of Japanese coastal industrialization since World War II has been an important model for China, and Japanese firms, the Japanese state, and Japanese banks play leading roles in the transferral of this model technologically, organizationally and financially to China. This model and the efforts underway to restructure the Chinese steel, coal, and other industries offer a potential avenue for a sustained process of economic ascent to core status and perhaps even to challenging for hegemonic status in the future. Our series of comparative historical cases that analyze how generative sectors form around raw materials and transport provide us with lessons that inform our analysis of this case of still uncertain outcomes in China.

Successfully following the Japanese model is only one potential future scenario for Chinese development. A second possible scenario is the formation of a Japanese-Chinese economic and political alliance similar to that between Great Britain and the U.S. in the I70os and I80os. Japanese financing and technology already combine in many industries to create some of the world's most competitive firms that dominate many industries and global export markets. In combination with China's conventional and nuclear military capabilities, this potential geopolitical and economic alliance could challenge U.S. hegemony.

Another possible future scenario for Chinese development is quite different. China faces both internal and external obstacles to this potential sustained economic ascent. Domestically, the huge social and political costs of moving from the model of autarky and guaranteed employment to global competitiveness are creating economic and political problems that will be difficult to resolve. Rising unemployment, growing rural-urban and geographic inequality, and decreasing political legitimacy of the Communist Party all threaten to create social disorder and even the breakdown of the Chinese political system.

Overall, in the context of competition in the global economy, replicating a highly successful model created during the I950s and I960s by Japanese firms and the Japanese state may not be sufficient to overcome existing and potential future challengers for economic ascent and hegemony. The next decade may bring a fundamental restructuring of the capitalist world-economy in support of sustained Chinese economic ascent, but China's economic ascent could also 
prove to be sharply constrained by economic and political competition, including the emergence of new organizational, technological, socioeconomic, or political innovations that increase scale and competitiveness in a rival economy and render China's immense investments in steel mills, coal mines, shipyards and other industries as relics of an earlier era of the world economy.

\section{REFERENCES}

Abegglen, James and George Stalk. 1985. Kaisha, The Japanese Corporation. New York: Basic Books.

Albion, Robert. 1926. Forests and Sea Power: The Timber Problem of the Royal Navy, 1652-1862. Cambridge: Harvard University Press.

Albion, Robert, William Baker and Benjamin Labaree. 1972. New England and the Sea. Middletown, CT: Wesleyan University Press.

Anderson, D. I987. "Japan's Coking Coal Procurement System: An Evaluation." Materials and Society II (I):23-36.

Arrighi, Giovanni. 1994. The Long Twentieth Century: Money, Power, and the Origins of Our Times. London: Verso.

Arrighi, Giovanni, Po-Keung Hui, Ho-Fung Hung, and Mark Selden. 2002. "Historical Capitalism, East and West." Paper presented at the 2002 American Sociological Association Annual Meeting.

Barbour, Violet. I930. "Dutch and English Merchant Shipping in the I7th Century." Economic History Review 2(2): 26I-290.

Barbour, Violet. I950. Capitalism in Amsterdam in the Seventeenth Century. Baltimore, MD: Johns Hopkins University Press.

Borden, William. I984. The Pacific Alliance: United States Foreign Economic Policy and Japanese Trade Recovery, 1947-1955. Madison: University of Wisconsin Press.

Boxer, Charles, 1965. The Dutch Seaborne Empire: 1600-1800. New York: Alfred A. Knopf.

Bridge, James. [1903] 199I. The Inside History of the Carnegie Steel Company. Pittsburgh: University of Pittsburgh Press.

Brizendine, Thomas and Charles Oliver. 200I. "China's Steel Sector in Transition." The China Business Review January-February:22-26.

Bunker, Stephen G. and Paul S. Ciccantell. 1995. "A Rising Hegemon and Raw Materials Access: Japan in the Post-World War II Era." Journal of World-System Research I(IO):I-3I. http://jwsr.ucr.edu 2003a * "Transporting Raw Materials and Shaping the World-System: Creating Hegemony via Raw Materials Access Strategies in Holland and Japan." Review: a Journal of the Fernand Braudel Center 26(4):339-380. 2003b. "Generative Sectors and the New Historical Materialism: Economic Ascent and the Cumulatively Sequential Restructuring of the World Economy." Studies in Comparative International Development 37(4):3-30.

Chandler, Alfred, ed. 1965. The Railroads: The Nation's First Big Business. New York: Harcourt, Brace and World.
. 1977. The Visible Hand: The Managerial Revolution in American Business. Cambridge, MA: Belknap Press of the Harvard University Press.

Chida, Tomohei and Peter Davies. 1990. The Japanese Shipping and Shipbuilding Industries, London: The Athlone Press.

Ciccantell, Paul. 200r. "NAFTA and the Reconstruction of U.S. Hegemony: The Raw Materials Foundations of Economic Competitiveness." Canadian Journal of Sociology 26(I):57-87.

Dorian, James. I999. "Mining in China: An Update." Mining Engineering 5I(2):35-4.

Frank, Andre Gunder. 1998. ReOrient: Global Economy in the Asian Age. Berkeley: University of California Press.

Graham, Paul, Sally Thorpe, and Lindsay Hogan. 1999. "Non-competitive Market Behaviour in the International Coking Coal Market." Energy Economics $2 \mathrm{I}(3) \div \mathrm{I} 95-2 \mathrm{I} 2$.

Harris, J.R. 1988. The British Iron Industry, 1700-1850. London: Macmillan.

Heinrich, Thomas. 1997. Ships for the Seven Seas: Philadelphia Shipbuilding in the Age of Industrial Capitalism. Baltimore. MD: Johns Hopkins University Press.

Herman, R. et al. 1989. "Dematerialization." Pp. 50-69 in Technology and Environment, edited by J. Ausubel and H. Sladovich. Washington, DC: National Academy Press.

Hobsbawm, Eric. 1968. The Age of Industry. New York: Charles Scribner's Sons.

Hogan, William. 1972. An Economic History of the Iron and Steel Industry in the United States. Lexington, MA: Lexington Books.

I999a. The Steel Industry of China: Its Present Status and Future Potential. Lanham, MD: Lexington Books.

. I999b. "The Changing Shape of the Chinese Industry." New Steel I5(II):28-29.

Holbrook, Stewart. I939. Iron Brew: A Century of American Ore and Steel. New York: The Macmillan Company.

Hui, Po-Keung. I995. "Overseas Chinese Business Networks: East Asian Economic Development in Historical Perspective." Ph.D. Dissertation, Department of Sociology, SUNY-Binghamton.

Huskonen, Wallace. 200I. "China Adds Three New Steel Mills." 33 Metalproducing April:26-27.

Innis, Harold. 1956. Essays in Canadian Economic History. Toronto: University of Toronto Press.

International Bulk Journal. I999. "China’s Surprise." October 23. . 2002. "China has its irons in the fire." May:28.

Invest in China. "Investment from Japan 1986-2002." Investment Promotion Agency of MOFCOM http://www.fdi.gov.cn. Retrieved September 19, 2004.

Irwan, Alex. 1995. "Japanese and Ethnic Chinese Business Networks in Indonesia and Malaysia." Ph.D. Dissertation, Department of Sociology, SUNY-Binghamton.

Isard, Walter. 1948. "Some Locational Factors in the Iron and Steel Industry Since the Early Nineteenth Century." Journal of Political Economy 63(3):203-217. 
Kahn, Joseph. 2003. "China Gambles on Big Projects for Its Stability." New York Times, January I3.

Katz, Richard. 1998. Japan: The System That Soured. Armonk. New York: M. E. Sharpe.

Koerner, Richard. I993. "The Behaviour of Pacific Metallurgical Coal Markets: The Impact of Japan's Acquisition Strategy on Market Price." Resources Policy March:66-79.

Kosai, Yutaka and Yoshitaro Ogino. 1984. The Contemporary Japanese Economy. Armonk, NY: M. E. Sharpe.

Lardy, Nicholas. I992. Foreign Trade and Economic Reform in China, 1978-1990. Cambridge: Cambridge University Press.

Larson, E., M. Ross and R. Williams. I986. "Beyond the Era of Materials." Scientific American, June:24-3I.

Liu, Kezhang and Xiaoyun Jin. 1994. "CC Gathers Speed in China." Steel Times International, January:40.

Livesay, Harold. 1975. Andrew Carnegie and the Rise of Big Business. Boston: Little, Brown and Company.

Mathias, Peter. 1969. The First Industrial Nation: An Economic History of Britain 1700-1914. New York: Charles Scribner's Sons.

McDougall, Walter. 1993. Let the Sea Make a Noise: Four Hundred Years of Cataclysm, Conquest, War and Folly in the North Pacific. New York: Avon Books.

McMillan, Charles. 1985. The Japanese Industrial System (Second Edition). Berlin: Walter de Gruyter.

Mehta, Manik. I998. "Winds of Change in China and India." Steel Times International, May.

Morison, Samuel. I921. The Maritime History of Massachusetts. Boston: Northeastern University Press.

Morris, Jonathan, John Hassard and Jackie Sheehan. 2002. "Privatization, Chinese-Style: Economic Reform and the State-Owned Enterprises." Public Administration 80(2):359-373.

O'Hearn, Denis, 2002. The Atlantic Economy: Britain, the U.S., and Ireland. Manchester: Manchester University Press.

Prigogine, Ilya and Isabelle Stengers. 1984. Order Out of Chaos: Man's New Dialogue with Nature. Toronto: Bantam.

Reutter, Mark. 1988. Sparrows Point: Making Steel-The Rise and Ruin of American Industrial Might. New York: Summit Books.

Rosenberg, Nathan and L.E. Birdzell. 1986. How the West Grew Rich: The Economic Transformation of the Industrial World. New York: Basic Books.

Ruiyu, Yin. I999. "Steel Technology in China." Steel Technology International 2000:27-32.

Schneider, Karen, Wu Zhonghu, Dai Lin, and Vivek Tulpule. 2000. Supplying Coal to South East China: Impacts of China's Market Liberalisation. Canberra: ABARE.

Serchuk, Alan. 200I. "Chinese Steel: Rousing the Phoenix." Modern Metals 57(I):32-
The Economic Ascent of China

Serrin, William. 1992. Homestead: The Glory and Tragedy of an American Steel Town. New York: Random House.

So, Alvin. 2003. "The Communist Path of Developmental State: The Chinese Experience." Paper Presented at the American Sociological Association Annual Meeting in Atlanta, GA.

So, Alvin and Stephen Chiu. I995. East Asia and the World Economy. Thousand Oaks, CA: Sage Publications.

Swan, Anthony, Sally Thorpe, and Lindsay Hogan. I999. "Australia- Japan Coking Coal Trade: A Hedonic Analysis under Benchmark and Fair Treatment Pricing." Resources Policy 25(I):15-25.

Tex Report. I994a. 1994 Coal Manual. Tokyo: Tex Report. . I994b. 1994 Iron Ore Manual. Tokyo: Tex Report.

33 Metalproducing. I998. "Chinese Steelmaking to See More Restructuring." September:40-42.

Todd, Daniel. 1996. "Coal Shipment from Northern China and its Implications for the Ports." The Dock and Harbour Authority 76(868):49-58.

Tse, Pui-Kwan, 2000. The Mineral Industry of China. Washington, DC: U.S. Geological Survey.

Wallerstein, Immanuel. 1974. The Modern World-System. New York: The Academic Press.

. 1982. "Dutch Hegemony in the Seventeenth-Century World Economy." Pp. 93-I46 in Dutch Capitalism and World Capitalism, edited by M. Aymard. Cambridge: Cambridge University Press.

Wang, Gungwu. I991. China and the Chinese Overseas. Singapore: Times Academic Press.

Warren, Kenneth. 1973. The American Steel Industry 1850-1970: A Geographical Interpretation. Oxford: Clarendon Press.

Yeung, Henry and Kris Olds, eds. 2000. Globalization of Chinese Business Firms. New York: St. Martin's Press. 43 